\title{
Research on the Legalization of College Student Management from the Perspective of Managing Schools by Law
}

\author{
Haiqiang Zhang \\ Weifang engineering Career Academy Automotive Engineering Department, Weifang Shandong \\ 262500, China. \\ 964086925@qq.com
}

Keywords: Student work management; Legal management; Ideological and political education.

\begin{abstract}
Current colleges and universities are faced with the challenge of cultivating innovative talents with the concept of "rule of law". The management of student work in colleges and universities can be based on the characteristics of running a university, and can be used to refine management guidelines; promote the construction of management teams, improve the work methods of the rule of law, and manage education services. Promoting the combination of "good governance" and "rule of law"; constructing multiple implementation channels, and improving the joint efforts of the rule of law, and other aspects of implementation, so as to lay a solid foundation for the country and society to cultivate advanced professionals who meet the spirit of the rule of law.
\end{abstract}

\section{Introduction}

The necessity of rule of law in the management of university students' work is an essential part of the socialist core values and is a necessary condition for promoting the all-round development of our country. The Fourth Plenary Session of the 18th CPC Central Committee further promoted the progress of the country's legalization. Among them, administering the school by law is an embodiment of the important strategy of governing the country according to law in the field of education. Student work management, as an important part of university management, is the main embodiment of managing the school according to law. The implementation of the rule of law management of student work can not only clarify the concept of running a university, highlight the characteristics of running a university [1], but also help to form a scientific and reasonable system implementation and supervision procedures, and standardize the student work management mechanism; at the same time, it also cultivates innovative talents with the spirit of the rule of law for the country. Provide protection, so as to further promote the construction of high-level universities. Therefore, the integration of the rule of law into student work management is an inevitable requirement and development trend of the times [2].

\section{The Urgency of The University's Management of Students According to Law}

\subsection{College Student Management Legalized School Management Requirements.}

Under the planned economic system, due to the high concentration of administrative power, colleges and universities, as legal entities undertaking public education services, often use administrative power as the center and rely on administrative orders to maintain the internal operation of the colleges and universities. It is difficult for students to find their rights in universities. The education law formulated on this basis is inevitably an education management law, and it is difficult to provide legal support for the protection of student rights and interests. This results in the fact that the relationship between universities and students is not completely equal and voluntary, and the rights and obligations are not completely equal. At present, although colleges and universities have implemented a number of reforms such as the charging system and the credit system, the color of administrative power in colleges and universities is still relatively strong [3], and students still have no civil legal relationship to obtain education services through the payment of tuition fees and the civil relations formed by colleges and universities. In the complete equality. In many cases, colleges 
and universities often use their own internal rules to restrict students, unilaterally make decisions to lift this civil relationship, and exclude some students based on these internal rules, fundamentally changing their legal status. The relationship between colleges and students is also different from ordinary administrative legal relations. In many cases, colleges and universities restrict or deprive students' rights according to their internal rules. Students do not have the right to raise objections to these rules. They only recognize and obey. These rules can only accept the results of the implementation of these rules in colleges and universities [4].

\subsection{University Student Management Rule of Law State Management Requirements.}

Managing the country according to law and building a socialist country under the rule of law is China's basic strategy. To implement this basic strategy in the field of higher education, it is necessary to administer education according to the law and administer the school in accordance with the law, and the student management must also introduce the concept of legalization. As an important way to achieve this strategy of governance, legal education has been absorbed into the modern higher education system and has become an integral part of modern higher education content. The legal education in modern colleges plays an irreplaceable role in establishing the country under the rule of law, cultivating the rule-of-law talents and cultivating law-abiding citizens. Colleges and universities must adapt to the requirements of establishing a "socialist country under the rule of law" and must be highly educated from both theoretical and practical aspects of university education. Pay attention to legal education. Today, the law has covered all areas of the country's political economy and social life. Legal quality has become the basic quality that individuals must possess. The implementation of the rule of law in student management work, improve the school's rules and regulations, and strictly abide by the rules, can form a good atmosphere for students to stress democracy and legal system, actively participate in the management of universities, and consciously safeguard school regulations. This is a powerful implicit legal education that enables all students to subconsciously and unknowingly develop ideological concepts and behavioral habits that conscientiously learn the law, consciously abide by the law, be good at usage, and be courageous to guard the law, so that legal education can be more effective. To contribute to the development of qualified successors in the rule of law [5].

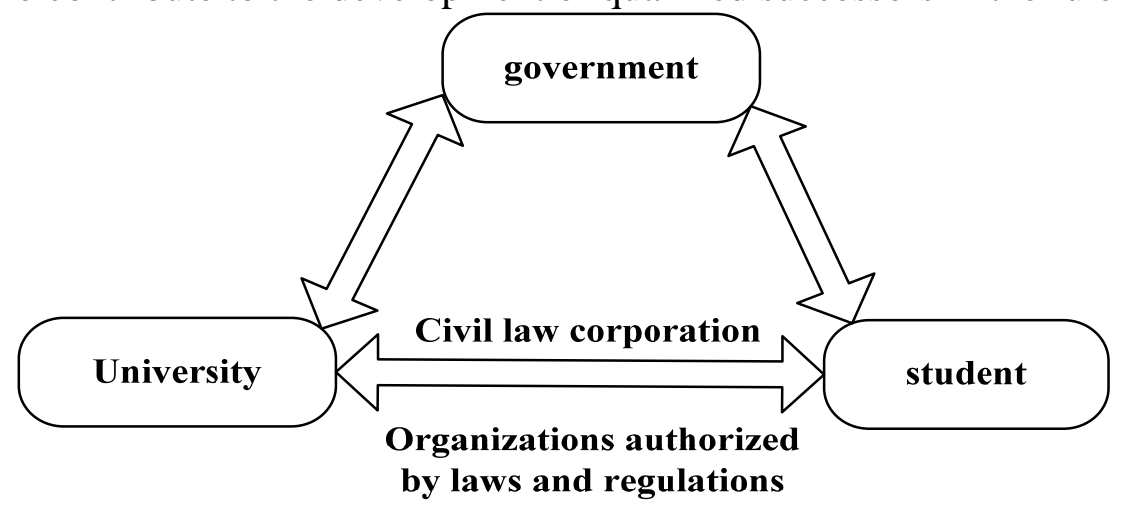

Fig 1. The role of parties in legal relationship

\section{Problems Existing in The Legalization of University Students' Work Management}

\subsection{The Lack of Management Rules in Universities.}

The failure to stipulate the details of the regulations governing universities and colleges The rules for the management of universities today are based on the Basic Law "Constitution", "Education Law", and "Law on Higher Education", and they are meticulously defined on the basis of the Basic Law "Regulations Governing Student Management in Higher Education Institutions". Implementation standards. However, the Basic Law and the Basic Law only clarified the principles of management, but seldom related to student work regulations. Therefore, most of the rules governing student work in colleges and universities stipulate the obligations students must perform, but they neglect the students' right to enjoy according to law. . As a result, the regulations governing student work in colleges and universities have not formed an orderly, complete and unified legal system. At 
the same time, due to the large number of declarative clauses in education laws and regulations, the implementation of procedural norms is relatively small, so that the management rules of universities are often convenient for themselves [6]. Management, ignoring the actual situation of the school and the characteristics of students, self-institutional regulations, resulting in some conflicts between the education regulations and the superior law, resulting in the implementation of the contradictory management system, so that managers in the handling of student work is indiscriminate, no evidence Can be in the state, resulting in a legal blind spot for university management.

\subsection{Oversight of Student Work Management Mechanism.}

Since ancient times, the administrators of the school have been highly authoritative and have strong commanding authority. Since most of the managers are from non-legal related majors, they have not learned and studied the corresponding concept of the rule of law, and they lack the corresponding "according to the law. "Consciousness and concept of governing school" has resulted in a work style of "parents" in the management of student work. They are accustomed to adopting traditional administrative orders and improperly driving education and management rights, resulting in frequent student status, degree awards, and graduation. There are disputes with students in employment, student behavior at school, etc., which infringe on students' basic rights. At the same time, the internal supervision of the organization of student work management authority has not yet been established or is not perfect, often resulting in the implementation and implementation of measures to "rule the school in accordance with the law" are not subject to the necessary restrictions, cannot effectively guarantee the exercise of the student's legal rights, resulting in the lack of implementation procedures Objectivity and scientific impair the right of students to obtain fair evaluations, thereby creating inequalities in rights and obligations between universities and students.

\subsection{The Students' Rule of Law Practice Concept Is Weak.}

With the rapid development of the society and the rapid changes of the times, many new features have emerged in contemporary students. For example, students in our college's innovative experiments in agricultural and forestry sciences show that they have high self-awareness, strong goals, active thinking, and easy acceptance of fresh ideas. Things, but in learning and life, they also highlight issues such as psychological relative impetuousness, over-practical values, and poor judgmental ability. At the same time, they lack the ability to self-discipline and the constraints of the social environment. As a result, they often show their personal interests in life. The degree of concern is higher than the social interest; in the study, it only focuses on professional innovation and scientific research, ignoring the training of the concept of the rule of law, resulting in the generalization and distortion of laws and regulations. This disparity between objective performance and subjective education philosophy has caused difficulties in the daily management of many students, and has brought enormous challenges to the implementation of the rule of law.

\section{Advancing the Path of Advancing the Rule of Law of College Students Management}

Under the background of governing the country according to law, in the face of the problems existing in the management of university students, only the management personnel of university students have changed their management concepts, established the concept of service and the concept of people-oriented, established and improved rules and regulations for student management, and established the proper procedures for student management. Only by perfecting the rights relief mechanism for college student management can we eventually promote the process of the legalization of college student management in China.

\subsection{Changing the Management Concept of College Students.}

\subsubsection{Establish the Concept of Equality.}

The idea of equality is the essential connotation of the rule of law. To realize the rule of law in the management process of college students, it is necessary to scientifically divide the rights and obligations of universities and students. In terms of the legal sense, the relationship between college administrators and students is equal, and university student managers do not have the power is above the students. Traditional respect for teachers and teachers often places too much emphasis on the 
main roles of managers and teachers. They do not place students on the other subjects in important positions. Students are generally at the margins and fail to achieve equal communication and dialogue with managers and teachers. Their rights and interests have not been well protected.

\subsubsection{Establish a People-Oriented Concept.}

People-centered practice advocates that human values are supreme and human rights are supreme. The essence of education is to promote people's all-round development. This is in line with the idea of people-oriented and ruled by law. To establish a people-centered concept requires that all students' administrators take student rights as the center when dealing with student affairs, and strive to create a relaxed, democratic, and rule of law environment for student development. This will ultimately benefit the growth of students and facilitate the completion of educational goals. . The managers, staff, and students involved in the management of college students are all different people. Therefore, school management eventually settles on the management of "people".

\subsubsection{Establish the Concept of Service.}

Management as a service is a concept promoted by modern management. Applying to the field of student management in colleges and universities, college student administrators can not only regard students as the objects to be managed, but also perform strict control and management. Students only belong to the subordinated dominant position. Practice has proved that with the increasing awareness of the rule of law of contemporary college students, this management approach will not work. To this end, college student managers should first of all correct their attitudes, establish a concept of service, enhance service awareness, improve service quality, and provide services for the growth of students. Secondly, to adjust the backward service mechanisms and methods, college administrators should actively innovate the student management model, take the initiative to serve the students, change the previous style of work, and actively prepare for the establishment of a new and effective student management model, forming a constraint on student management efficiency.

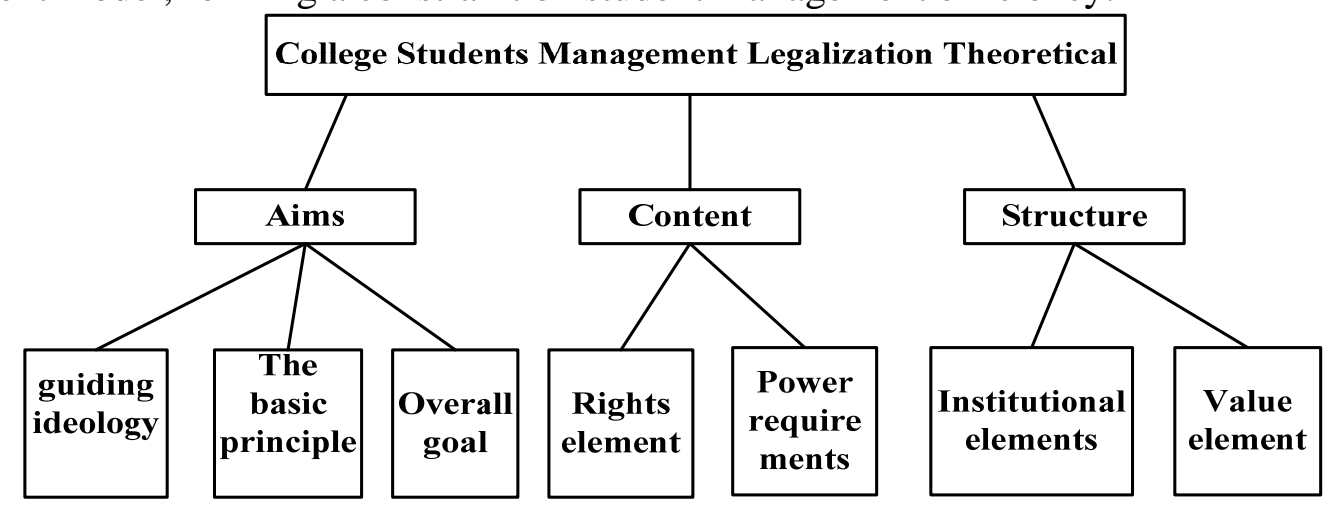

Fig 2. College student's management legalization theory system diagram

\subsection{Establishing and Improving the Laws, Regulations and Rules for the Management of College Students.}

\subsubsection{Intensify the Legislative Efforts on College Student Management.}

In recent years, China's educational legal construction has made great progress, but there is still a certain gap with the "rule of law" strategy put forward by the state. Some laws relating to student management still have certain vacancies, especially in large-scale examinations that frequently appear in society in recent years, and even national examinations (graduate entrance examinations, college entrance examinations) have cheated. The country has no relevant legislation, and in dealing with these events, Not easy to grasp. At the same time, it is necessary to strengthen the procedural legislation, improve the operational norms and provability of relevant laws and regulations concerning student management, make the "Education Law", "Law of Higher Education" and other laws and regulations related to student management, and establish and improve the internal management system of universities. The rules and regulations for student management established by colleges and universities are the internal "laws" of universities. The rules and regulations for student management formulated by universities should follow the following principles: The first is the principle of legality, that is, the "law" within universities must not conflict with current laws and 
regulations. It should be in accordance with the current education laws and regulations, in conjunction with the current rules and regulations for the development of schools; followed by the principle of rationality, that is, colleges and universities in the development of internal "law" must be reasonable, in line with the fair and reasonable jurisprudence, if not Because the school is late for students to stay in school to see the punishment; the last is the principle of democracy, that is, colleges and universities in the system within the "Law" when not only to listen to the views of student managers advice, but also to listen to the views of the majority of students, so that the development of the regulations The implementation of the system is easy to get recognition of the majority of students, but also more in line with the reality of students.

\subsubsection{Constructing the Due Process of College Student Management}

The connotation of due process is neutral, fair, open, actionable, exclusive, self-governing, and timely completion, and legal authority can be achieved through due process. In the field of education, university administrators should pay attention to strengthening their procedural awareness when dealing with student incidents, so that the concept of due process can be infiltrated into all aspects of student management. In particular, students' rights to information should be fully respected when dealing with student decisions. Right of defense, right of hearing and hearing, right to appeal afterwards, right to remedy, etc., can effectively regulate the operation of power through the effective use of due process, control the process of handling students, and ensure the openness, fairness, and fairness of the process, so as to maximize the protection of students' rights and interests. .

\subsubsection{Improve the Rights Relief Mechanism for College Student's Management.}

Relief is an important part of the legal process. The right without remedy is not guaranteed. The relevant provisions of the relevant laws and regulations on remedies are relatively vague. Therefore, from the perspective of the legal system, the protection channels for students' rights in universities are mainly the following: Establishing and improving the complaints system. At present, whether it is school appeals or off-campus administrative appeals, the relevant procedures and rules are not very sound. A complaint system should be established as soon as possible, and complaint handling measures should be improved to ensure that students' rights protection actions are implemented and resolved as soon as possible. Because dealing with the professional management of college students, the establishment of an educational arbitration mechanism is conducive to promptly resolving disputes, reducing the costs of parties to disputes, and effectively overcoming the limitations of professional knowledge when courts try educational disputes, and at the same time reducing costs and saving unnecessary disputes. Cost of. The education arbitration system can be used as a transitional link between the education appeal system and the education litigation system. The protection of students' litigation channels is the most thorough solution, with broad impact and comprehensive protection of rights. It is the last line of defense to achieve social justice. The way of university student rights remedy based on lawsuit is the result of the joint action of the rule of law of higher education and the individual rights protection of students in our country. Through judicatory intervention review, the management rights of college students can be supervised and restricted to a certain extent, so as to better protect the rights and interests of students and promote the process of the legalization of university student management in China.

\section{Conclusion}

With the deepening of the socialist legal construction, the legalization of the management of university students has been given more attention and development. The management of student affairs in colleges and universities is only within the scope of national laws. It establishes and gradually perfects the corresponding management system in colleges and universities, fulfills various tasks in student affairs management according to law, inherits the "people-oriented" core education concept, and is based on ideological and political education. Combining the "rule of the person" education with the "rule of law" management approach to ensure scientific management, humanistic education, and meticulous service, provide students with adequate educational resources and environment, and guide them to conduct independent evaluation, prediction, and judgment. Ability to 
protect the legitimate rights and interests of their education, in order to achieve the purpose of cultivating advanced professionals who meet the spirit of the rule of law for the country and society.

\section{References}

[1]. Zhang Xiao Juan, et al. Analysis of the Legalization of College Student Management. Journal of Shanxi Normal University: Social Sciences, Special Issue for Graduate Student's thesis, Vol. 3 (2011) No.141-146.

[2]. Ma Xiao, Zha Zhuang, ET al. Research on the Legal System of University Student Management and the Construction of the Legal Model of Work. Journal of Handan University, Vol. 6 (2007) No.17. p. 294-298.

[3]. Xu Flanging, et al. the role of counselors in the process of the legalization of college student management. Journal of Fujian Education Institute, Vol. 7 (2010) No. 25, p.212-217.

[4]. Qi Yuan Jun, Liu Xiao, et al. Analysis of the Legalization of College Student Management. Journal of Shandong University of Technology: Social Science Edition, Vol. 9 (2005) No. 23, p.189-194.

[5]. Li Yan, et al. Study on the Legalization of College Student Management. Dalian: Dalian University of Technology, Vol. 2 (2010) No. 29, p.126-131.

[6]. Ma Jaiden, et al. Study on the Legalization of Student Management in Higher Vocational and Technical Colleges. Chongqing: Southwest University, Vol. 5 (2006) No. 36, p.215-219. 